\title{
INVESTIGATION OF DINAMICAL VISCOSITY OF WATER SUSPENSION OF SHIITAKE SPOROCARP
}

\author{
N. Sharkova, E. Zhukotsky, G. Dekusha, L. Kostyanets \\ National University of Food Technologies
}

\begin{tabular}{|c|c|}
\hline Key words: & ABSTRACT \\
\hline Aqueous colloid-dispersed & The article presents the investigantions of reducing the \\
\hline $\begin{array}{l}\text { sion of the fruit } \\
\text { f the shiitake }\end{array}$ & $\begin{array}{l}\text { viscosity of an aqueous colloid-dispersed suspension of the } \\
\text { fruit body of shiitake mushroom with the aim of its further }\end{array}$ \\
\hline fungus & technological regimes, \\
\hline Dynamic viscosity & at on its rheological \\
\hline Technological regimes & st significant influence on \\
\hline Rotary pulsation & $\mathrm{n}$ is \\
\hline apparatus & and \\
\hline $\begin{array}{l}\text { Discrete-impulse energy } \\
\text { input method }\end{array}$ & addition of a structuring additive $\beta$-cyclodextrin. The quality \\
\hline $\begin{array}{r}\text { Art } \\
\text { Received }\end{array}$ & on its rheological properties. \\
\hline
\end{tabular}

Received in revised form

23.11.2017

Accepted 22.12.2017

Corresponding author:

N. Sharkova

E-mail:

npnuht@ukr.net

DOI: $10.24263 / 2225-2924-2017-23-6-28$

\section{ДОСЛІДЖЕННЯ ДИНАМІЧНОЇ В'ЯЗКОСТІ ВОДНОЇ СУПЕНЗЇ ПЛОДОВОГО ТІЛА ГРИБА ШИЇТАКЕ}

\author{
Н.О. Шаркова, Е.К. Жукотський, Г.В. Декуша, Л.О. Костянець \\ Національний університет харчових технологій
}

У статті вивчено можливість зниження в'язкості водної колоїдно-дисперсної суспензії плодового тіла гриба шиїтаке з метою подальшої ії подачі на розпилювальне сушіння. Визначено вплив теплотехнологічних режимів, добавок і конструктивних особливостей обладнання на реологічні властивості грибної суспензії. Встановлено, що збільшення гідромодуля, температури та кількості внесеної структуруючої добавки - $\beta$-ичиклодекстрину найкращим чином сприяють зниженню в'язкості грибної суспензії. Категорія якості гриба, його структурні частини та тип конструкиії роторно-пульсаиійного апарата мали найменший вплив на ї̈ реологічні властивості.

Ключові слова: водна колоїдно-дисперсна суспензія плодового тіла гриба шиїтаке, динамічна в'язкість, технологічні режими, роторно-пульсаційний апарат, метод дискретно-імпульсного введення енергї̈. 
Постановка проблеми. Сьогодні у всьому світі зростає зацікавленість до східної фунготерапії - традиційного способу лікування цілющими грибами. Серед них японський гриб шиїтаке за останні десятиліття став справжньою сенсацією і в загальному світовому об'ємі вирощуваня грибів посідає третє місце $(12,3 \%)$ після шампіньйонів і гливи $[1 ; 2]$. Західна медицина вкладає колосальні кошти в дослідження шиїтаке і наукові дослідження однозначно підтверджують лікувальні властивості гриба: протипухлинні, імуномодулюючі, антивірусні, антиоксидантні, сорбційні [3-7].

Унікальні властивості гриба проявляються завдяки його незвичайному хімічному складу (білки $-10 \ldots 17 \%$, жири $-0,6 \ldots 8,0 \%$, вуглеводи $-67 \ldots 78 \%$, зола $-3,7 \ldots 10 \%$ за сухою масою). Зокрема, гриб містить унікальний комплекс полісахаридів з імуномоделюючими властивостями, білки, які містять всі незамінні для людини амінокислоти, комплекс вітамінів, незамінні поліненасичені жирні кислоти, широкий спектр найважливіших макро- i мікроелементів, серед яких ідефіцитний у нашому харчуванні селен.

Тому сьогодні створення новітніх продуктів і дієтичних лікувально-оздоровчих добавок на основі гриба шиїтаке можна віднести до ефективних способів підтримуючої імунотерапії при низці захворювань. До того ж для гриба шиїтаке характерна простота цілорічного вирощування, висока врожайність, екологічність і, відповідно, рентабельність [1].

При виробництві сухих порошкових форм плодових тіл базидіальних грибів застосовують, як правило, конвективне сушіння або сушіння інфрачервоними променями 3 подальшим сухим помелом висушеного матеріалу. Ці способи сушіння мають ряд недоліків: тривалість у часі, недостатня ступінь дисперсності порошків і низькі мікробіологічні показники, до того ж отримані порошки можуть використовуватись лише після додаткової термічної обробки. Для усунення зазначених вище недоліків авторами запропоновано використання методу розпилювального сушіння при створенні нових продуктів на основі гриба шиїтаке для лікувально-оздоровчого харчування.

У зв'язку з практичним інтересом до полісахаридів лікувального гриба шиїтаке особлива роль відводиться реологічним властивостям розчинів полісахаридів, для яких характерна аномальна в'язкість.

Метою статті є дослідження реологічних властивостей грибної суспензії плодового тіла гриба шиїтаке, отриманої при різних теплотехнологічних режимах гідродинамчної обробки із застосуванням методу дискретно-імпульсного введення енергії (ДІВЕ) та встановлення раціональних режимів іiї отримання для подальшої подачі на розпилювальне сушіння.

Матеріали і методи. Матеріалами для проведення експериментальних досліжень $\epsilon$ водна колоїдно-дисперсна грибна суспензія плодового тіла гриба шиїтаке та функціональні добавки (хлористий натрій, мальтодекстрин i $\beta$-циклодекстрин).

Динамічну в'язкість усіх зразків грибної суспензії визначали на ротаційному віскозиметрі Brookfield DV-E (виробник США). При порівнянні в'язкостей неньютонівських рідин при всіх її вимірюваннях використовували одне й те саме поєднання - «швидкість обертання - шпиндель». Дане поєднання обирали таким чином, щоб діапазон вимірів знаходився між 45 і 95\% поділ- 
ками повної шкали. Всі дослідження динамічної в'язкості зразків грибної суспензії проводили на шпинделі № 64 при швидкості обертів $50 \mathrm{xв}^{-1}$.

Для обробки отриманих результатів експериментальних досліджень використано статистичні та математичні методи.

Результати і обговорення. При підготовці гриба шиїтаке до сушіння основним технологічним етапом $є$ процес отримання водної колоїдно-дисперсної системи гриба, який складається з його попереднього подрібнення та подальшої гідродинамічної обробки. Матеріал, який подається на розпилювальне сушіння, повинен бути певної консистенції і характеризуватись значеннями динамічної в'язкості $0,6 \ldots 0,8$ Па · c.

Для отримання водної дисперсії плодового тіла гриба шиїтаке нами досліджено можливість застосування розробленого в ІТТФ НАН України методу ДIВЕ, що реалізований у роторно-пульсаційних апаратах (РПА) різних типів і успішно зарекомендував себе в багатьох харчових технологіях при гідродинамічній обробці різноманітних складних багатокомпонентних гетерогенних систем для отримання стійких дисперсій за умов не значних енерговитрат [8; 9].

У ході досліджень грибної суспензії встановлено, що при диспергуванні гриба шиїтаке за допомогою методу ДІВЕ без внесення води або з мінімальною ії кількістю утворюється стійка нерухома колоїдно-дисперсна суспензія гелеподібної консистенції, яка унеможливлює подальший процес подачі ії в розпилювальну сушарку. Нами проведено комплекс експериментальних досліджень щодо визначення впливу виду диспергуючого обладнання, принцип роботи яких заснований на механізмах ДIBE, та різних тепло-технологічних режимів на зниження в'язкості грибної суспензії, а саме: конструкція РПА, зміна гідромодуля, температури грибної суспензії та внесення структуруючих добавок.

Вплив типу РПА на зміну динамічної в'язкості водної грибної суспензії визначали на двох РПА, розроблених і виготовлених в ІТТФ НАН України:

1. РПА-Л, що складається із 2 роторів та 1 статора, $n=3000$ об./хв;

2. РПА-Ж, що складається із 2 статорів та 1 ротора, $n=6000$ об./хв.

Паралельно визначали вплив росту гідромодуля від 1 до 2 (за масою) та температури $\left(t=20 \ldots 80^{\circ} \mathrm{C}\right)$ на зміну динамічної в'язкості грибної суспензії.

До наважки дрібних плодових тіл гриба шиїтаке, попередньо подрібнених до розмірів $2 . .3$ мм, додавали у необхідній кількості воду температурою $\mathrm{t}=$ $20^{\circ} \mathrm{C}$ і диспергували в РПА певного типу. Динамічну в'язкість отриманого зразка грибної суспензії вимірювали при температурах $20^{\circ} \mathrm{C}, 40^{\circ} \mathrm{C}, 60^{\circ} \mathrm{C}$ i $80^{\circ}$ С. Результати зміни динамічної в'язкості грибної суспензії залежно від конструкції РПА, гідромодуля й температури наведено на рис. 1.

Залежності, наведені на рис. 1, свідчать, що на зниження в'язкості грибної суспензії найсуттєвіший вплив чинить ріст гідромодуля: в межах від 1 до 2 при $20^{\circ} \mathrm{C}$ в'язкість суспензії зменшується в середньому в 3 рази (з 3,2 до 1,1 Па $\cdot$ c) незалежно від конструкції РПА. При нагріванні всіх зразків водної грибної суспензії від 20 до $80^{\circ} \mathrm{C}$ їх в'язкість знижується в середньому в 2 рази.

Зниження динамічної в'язкості грибної суспензії з ростом температури можна пояснити тим, що полісахариди, які складають більшу частину гриба за сухою масою, відносяться до аморфних речовин. Їх макромолекули розміщені не щільно і в результаті нагрівання між гнучкими ланцюгами полі- 
сахаридів утворюються отвори, в які проникають молекули розчинника і в'язкість грибної суспензії знижується.

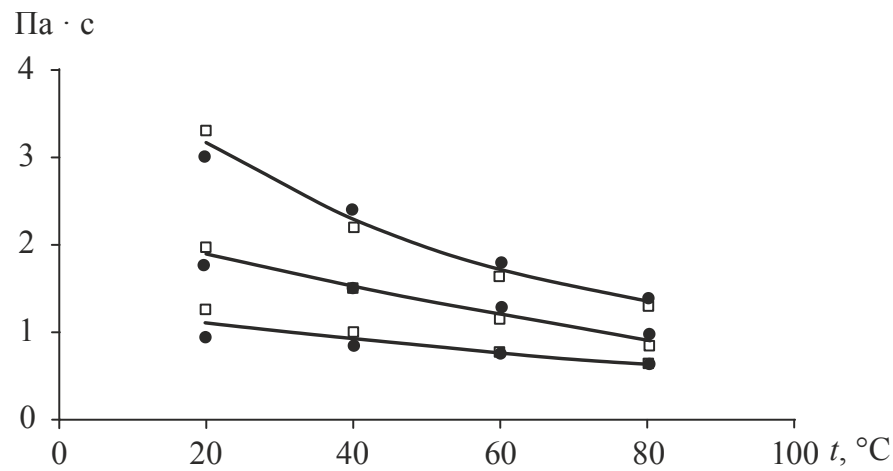

Рис. 1. Залежність динамічної в'язкості грибної суспензії, що приготовлена на РПА різних конструкцій ( - РПА-Л, • - РПА-Ж) від температури при гідромодулях:

1 - гідромодуль $1 ; 2$ - гідромодуль 1,$5 ; 3$ - гідромодуль 2

Найменше на в'язкісні характеристики грибної суспензії впливали констркуційні особоливості РПА, для подальшої роботи було обрано РПА-Ж.

Виходячи 3 отриманих результатів, для проведення подальших досліджень використовували водну грибну суспензію, приготовлену із гідромодулем 1,5.

Відомо, що порівняно з шапками, ніжки грибів містять більше хітину (масове співввідношення ніжка:шапка складає 1:3) — азотвмісного полісахариду, який надає структурної міцності клітинним оболонкам гриба. Проведено порівняння в'язкісних показників зразків грибних суспензій, виготовлених із цілих грибів та їх структурних частин різної категорії якості: дрібних грибів, несортових грибів і шапок несортових грибів. Усі зразки приготовлено, як описано вище (гідромодуль грибної суспензії 1,5, РПА-Ж, діапазон температури $\left.20 \ldots 80^{\circ} \mathrm{C}\right)$. Залежність динамічної в'язкості зразків грибної суспензії, виготовлених із різних частин плодового тіла гриба шиї таке, від температури наведено на рис. 2.

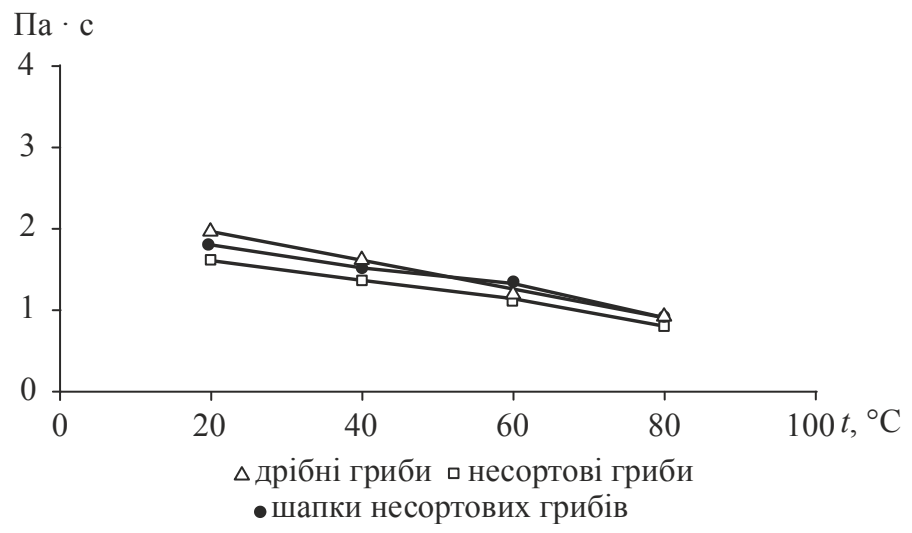

Рис. 2. Залежність динамічної в'язкості зразків грибної суспензії, виготовлених із різних частин гриба шиїтаке, від температури 
3 отриманих залежностей (рис. 2) видно, що всі зразки грибної суспензії близькі за значеннями у всьому діапазоні температур, тому далі використовували цілі несортові гриби. Окрім того, що вони мають аналогічний до дрібних грибів хімічний склад, їх доцільніше використовувати і з економічної точки зору - несортові гриби шиїтаке в 1,5 раза дешевші за дрібні гриби. Станом на квітень 2017 р. вартість 1 кг цілих сортових дрібних грибів становила 90 грн, несортових - 60 грн/кг.

У харчоконцентратній промисловості при розпилювальному сушінні продуктів рослинного походження, що містять складні високомолекулярні сполуки, вносять структуруючі добавки, які сприяють покращенню умов перебігу процесу сушіння, покращують якість, функціональні та смакові властивості висушеного продукту. Для підбору найбільш ефективної добавки, яка могла б знизити в'язкість суспензії, не погіршуючи при цьому інші функціональні властивості суспензії, нами досліджено вплив деяких речовин на в'язкість грибної суспензії: хлористий натрій, мальто- та $\beta$-циклодекстрин.

Залежність в'язкості зразків грибної суспензії з масовою концентрацією хлористого натрію $(\mathrm{NaCl}): C_{1}=0,6 \%, C_{2}=3,6 \%$ (від загальної маси зразка) та контролю (умови приготування як і в попередніх дослідах) від температури наведено на рис. 3.

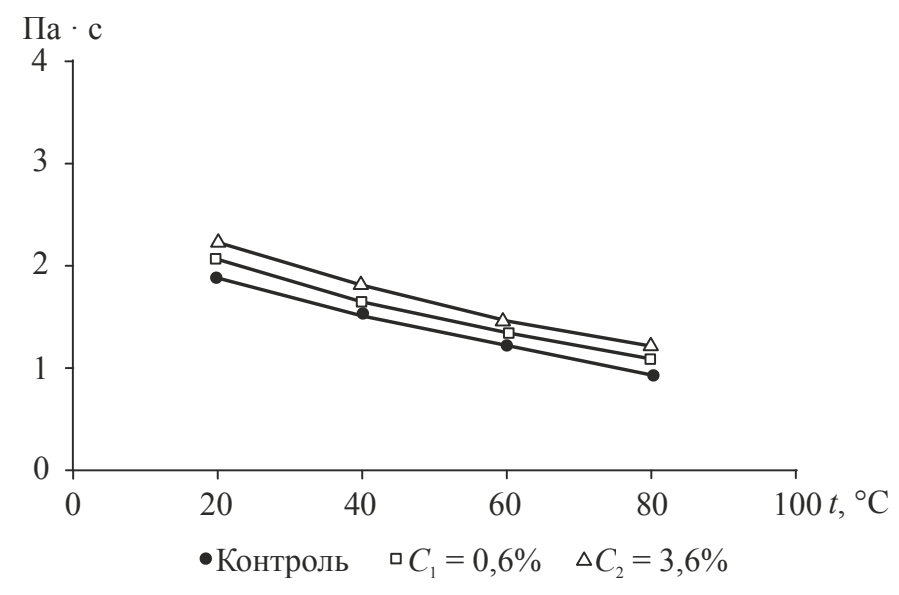

Рис. 3. Залежність динамічної в'язкості грибної суспензії при різних масових частках хлористого натрію від температури

3 рис. 3 видно, що при загальному зниженні динамічної в'язкості всіх зразків з ростом температури з 20 до $80^{\circ} \mathrm{C}$ в 2 рази додавання хлористого натрію до суспензії призводить до підвищення ії в'язкості на $15 \ldots 20 \%$ порівняно з контролем у всьому діапазоні температур.

При роботі з грибами шиїтаке до суспензії додавали харчову добавку мальтодекстрин $з$ декстрозним еквівалентом (DE) 18, який використовується як стабілізуюча добавка у харчових об'єктах розпилювального сушіння: у спортивному харчуванні та дитячих сумішах [10]. Залежність динамічної в'язкості грибної суспензії з масовою часткою мальтодекстрину $C=5 \ldots 15 \%$ від температури наведено на рис. 4. 


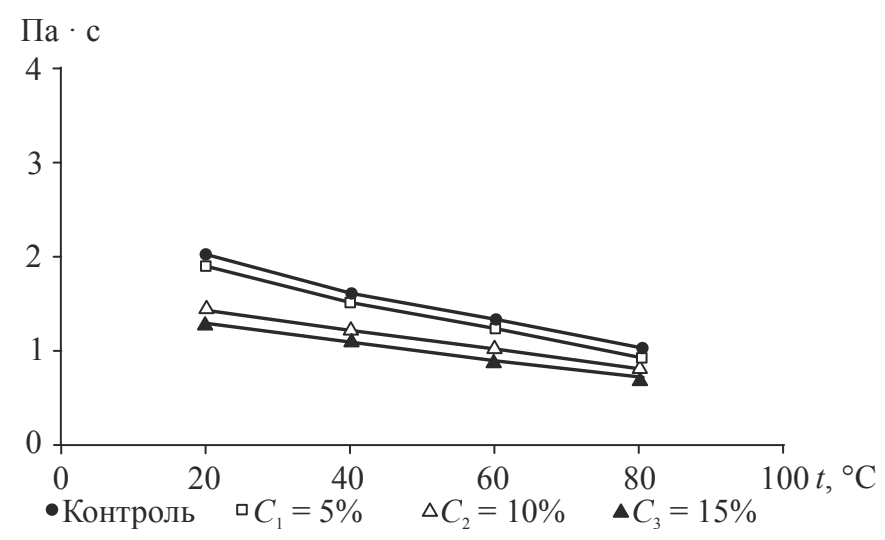

Рис. 4. Залежність динамічної в'язкості грибної суспензії при масових частках мальтодектсрину від температури

Як видно з рис. 4, більш істотне зниження в'язкості грибної суспензії (від $25 \ldots 30 \%)$ з внесенням мальтодекстрину у кількості $\geq 10 \%$ відбувається вже при температурі $20^{\circ} \mathrm{C}$, що $є$ важливим технологічним фактором для подачі продукту на розпилювальну сушарку.

$\beta$-циклодекстрини давно зарекомендували себе як ефективний інструмент для створення препаратів з покращеними властивостями. Це циклічний олігомер із 7 залишків глюкози, отриманий ферментативним шляхом із крохмалю. На зовнішній стороні кільця розташовані гідрофільні групи, а в центрі кільця відносно неполярна порожнина-кларат, де можуть розміщуватись невеликі молекули. Завдяки своїй структурі вони здатні до молекулярної інкапсуляції речовин, допомагають підвищити розчинність, біодоступність і стабільність матеріалів, маскують небажаний смак і запах, завдяки чому широко використовується у фармацевтиці та косметичній промисловості [11].

На рис. 5 наведено залежність динамічної в'язкості зразків грибної суспензії з внесенням $\beta$-циклодекстрину $-C_{1}=2,5 \%$ та $C_{2}=5 \%$ в температурному діапазоні $20 \ldots 80^{\circ} \mathrm{C}$.

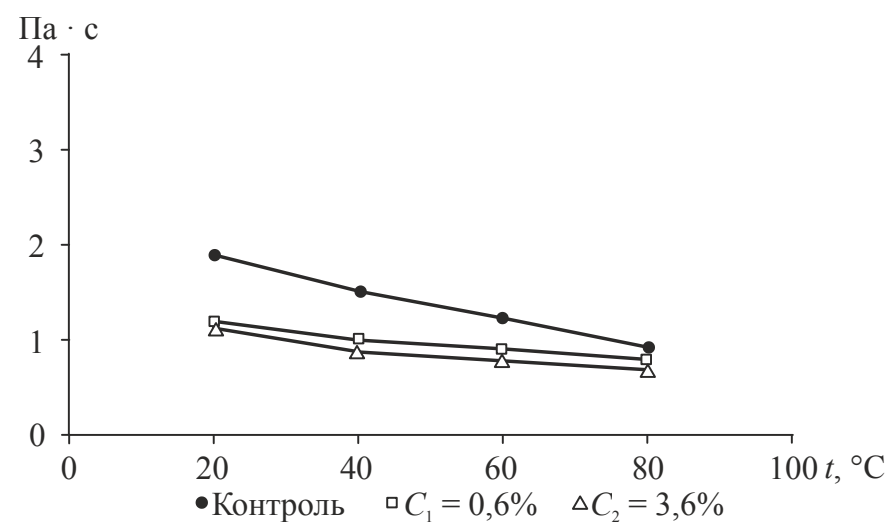

Рис. 5. Залежність динамічної в'язкості водної грибної суспензії при різних масових частках $\beta$-циклодекстрину від температури 
В'язкість зразків водної грибної суспензії із ростом в ній масової частки $\beta$-циклодекстрину до $5 \%$ і температури до $80^{\circ} \mathrm{C}$ зменшується порівняно 3 контролем в 1,6 раза і досягає необхідних значень - 0,6...0,8 Па · с. Подальше збільшення масової частки $\beta$-циклодекстрину в грибній суспензії не призводить до суттєвого розрідження суспензії і $€$ недоцільним.

\section{Висновки}

Встановлено, що необхідні для подачі в розпилюючу сушарку реологічні показники грибної суспензії, які знаходяться в межах $0,6 \ldots 0,8$ Па · с, досягаються при гідромодулі приготування суспензії - 1,5 та нагріванні іï до температури $80^{\circ} \mathrm{C}$. Введення декстриновмісних добавок дає змогу знизити в'язкість грибної суспензії на $25 . . .35 \%$ у всьому діапазоні температур.

\section{Лiтература}

1. Гриби [Електронний ресурс]. — Режим доступу : http://ikc.belapk.ru/assets/files/issledovaniya/griby_2015.pdf.

2. Сімахіна Г.О. Виробництво сухого грибного напівфабрикату для збагачення харчових раціонів / Г.О. Сімахіна, І.Ю. Гойко // Наукові праці Національного університету харчових технологій. - 2015. - Т. 21, № 2. - С. 190-196.

3. «Наука и жизнь». Японский гриб шиитакэ [Електронний ресурс]. — Режим доступу: http://www.nkj.ru/archive/articles/2832.

4. Технологии грибоводства [Електронний ресурс]. — Режим доступу : http://wer23sd.narod.ru/inf.html.

5. Richard Sullivan Medicinal Mushrooms: Their therapeutic properties and current medicalusage with special emphasis on cancer treatments. -2002 . $-256 \mathrm{p}$.

6. Brauer D. Potential for manipulating the polysaccaride content of shiitake mushrooms / D. Brauer, T.E. Kimmons, M. Phillips // Applied microbiology and Biotecnology. — 2010. P. 1136-1142. — ISSN 0175-7598.

7. Fungi applications and menegment strategies / Editors S.K. Deshmukh, J.K. Misra, J.P. Tewari, Tamas Papp International Standart Book Number-13: 978-1-4987-2492-0. — $472 \mathrm{p}$.

8. Долинский А.А. Принципы разработки новых энергосберегающих технологий и оборудования на основе методо дискретно-импульсного ввода энергии / А.А. Долинский, Г.К. Иваницкий // Промышленная теплотехника. — 1997. — Т. 19. — № 4-5. — С. $13-15$.

9. Промптов М.А. Пульсационные аппараты роторного типа: теория и практика. Москва :Машиностроение, 2001. - 260 с.

10. Литвяк В.В. Получение и исследование мальтодекстринов / В.В. Литвяк // Пищевая промышленность: наука и технологии - 2014. - № 4(26) - С. 15-27.

11. Elham Blouet Нативные и модифицированные циклодекстрины KLEPTOSE: многофункциональные вспомогательные вещества для молекулярной инкапсуляции // Спеціальний випуск «Ингредиенты для фармации». «Фармацевтическая отрасль». — 2015. № $5(52)$. - C. $52-56$. 